\title{
LIPID PEROXIDATION IN SEMEN OF THE BOAR
}

\author{
M. SMUTNÁ, O. SYNEK \\ Department of Chemistry, Physics and Biochemistry, University of Veterinary Science, 61242 Brno
}

Received February 6, 1979

\begin{abstract}
Smutná M., O. Synek: Lipid Peroxidation in Semen of the Boar. Acta vet. Brno, 48, 1979: 35-43.

During the catalyzed aerobic incubation of the complete boar semen malonyldialdehyde (MDA) is produced. MDA is a good indicator of peroxidative decomposition of polyunsaturated fatty acids. Detection of peroxidation products was conducted both by colour reaction with 2-thiobarbituric acid (evidence of MDA), and spectrofotometrically (evidence of the conjugated dienes, oxidation of the coenzyme NADPH $+\mathrm{H}^{+}$). It was found that the progressive formation of MDA surpasses the formation of conjugated dienes especially in the early stages of peroxidation. Significant correlation for the first 30 minutes of the aerobic incubation was found between the number of spermatozoa and the amount of produced malonyldialdehyde.

Enzymatic lipid peroxidation studied in isolated tails of spermatozoa was NADPH-dependent with a small dependence on pyrophosphate. Production of MDA in all studied systems was influenced by $\mathrm{pH}$ of the environment.

The boar seminal plasma showed high anti-peroxidative activity limited by its dilution.
\end{abstract}

Native semen, malonyldialdehyde, conjugated dienes, inhibitory effect.

Properties of the membranes determine largely the properties of the cells and tissues. Viability of each animal cell depends on structural and functional integrity of its membrane and subcellular structures. The quality of the membrane is also important for viability of spermatozoa and for metabolic processes ensuring their contact to the environment. Changes in the properties of these membranes result in functional and morphological aberations the character of which is given by the degree of damage to the membrane.

The labile compound of the membranes are unsaturated fatty acids esterified in phospholipids which together with globular proteins represent the basic structural components of all biological membrane complexes. Non-enzymatic peroxidative breakdown of unsaturated fatty acids of the membrane to small fragments impairs their function in the lipoprotein membrane and injurs seriously their structural and functional integrity. Destruction of specific membrane phospholipids during the NADPH-induced lipid peroxidation of the microsomal fraction from rat liver was demonstrated by $M$ a y and Mc Cay (1968). Decomposition by peroxidation of the chain of polyunsaturated fatty acids esterified in the beta position of phosphatidylcholine and phosphatidylethanolamine of the microsomal membrane resulted in a $40 \%$ decrease in the amount of arachidonic acid. The harmful effect of $\mathrm{H}_{2} \mathrm{O}_{2}$ and dialuric acid on the erythrocyte membranes in rats suffering from $\mathrm{E}$ hypovitaminosis lead to partial damage to phosphatidylethanolamine, phosphatidylcholine and phosphatidylserine (Heikkila et al. 1971). Changes in the concentration of phospholipids in the boar semen were found to be caused by its aerobic incubation with $\mathrm{Cu}^{++}$ ions (S mutná 1974). Loss of plasmalogen and palmitaldehyde from the ram sperm and loss of motility of spermatozoa with their spontaneous agglutination was found by Jones and Mann (1976). Damage to ram spermatozoa due to peroxidation of endogenous phospholipids was observed by the same authors (Jones and Mann 1977). Impaired functional integrity manifesting itself by changed permeability to $\mathrm{K}^{+}$and $\mathrm{Na}^{+}$in irradiated erythrocytes was demonstrated by $\mathrm{Gerber}$ and Altman (1970), glucose efflux through an artificially prepared membrane (Hicks and Gebicki 1977) and impaired permeability of $E$. coli membrane for the $\mathrm{K}^{+}$ions were observed (Suzuki and Akamatsu 1978). 
The boar sperm with the high content of unsaturated fatty acids in phospholipids of spermatozoa is a suitable substrate for the study of non-enzymatic and enzymatic lipid peroxidation. Particularly high unsaturated fatty acid content, namely $73 \%$, is in phosphatidylcholine, followed by phosphatidylethanolamine containing $64 \%$ of unsaturated fatty acids. Among these predominate the docosapentaenoic acid $(22: 5 \omega 6)$ and docosahexaenoic acid (22:6). Smaller proportions are of the oleic, linoleic, linolenic and arachidonic acids (Johnson et al. 1969a, 1969b, 1972).

Lipid peroxidation in the sperm of farm animals has been hitherto studied only scarcely although the deteriorating effect of air oxygen and $\mathrm{H}_{2} \mathrm{O}_{2}$ (both exogenous and endogenous) on viability and metabolic activity of spermatozoa of various animals species has been known for more than 30 years (Mc Leod 1943; Prince and Almquist 1948). The influence of ageing of sperm on lipid peroxidation of the boar spermatozoa was studied by Mrotek et al. (1966), lipid peroxidation in the boar sperm was described by Hruška et al. (1970), and in the ram sperm by Jones and Mann (1973).

These data indicate that the phospholipids form a dynamic component in the membrane of spermatozoa which reacts rapidly and sensitively to the injurious factors of the environment (undue manipulation, dilution, cold shock, freezing and thawing of the sperm, method of sperm conservation) inducing changes of the fatty acids. Oxidized or decomposed fatty acids do not fulfill their functions, and consequently, impaired integrity of cell membranes and fertilizing ability of spermatozoa follow.

The aim of the present work is to study the changes of fatty acids from spermatozoa phospho-lipids during a catalyzed aerobic incubation of native boar semen.

\section{Material and Methods}

For experiments, semen from 4 White Purebred and one Piétrain boars of the Veterinary Re-search Institute, Brno, was used. Housing and feeding of the animals was in agreement with the Czechoslovak norm standard. Semen was collected by artificial vagina and a dummy. The laboratory control was provided at the above-mentioned Institute. The semen separated from the gel. was carefully transported to our laboratory and processed immediately.

For the study of lipid peroxidation in the boar sperm the following methods were elaborated. and successfully employed:

\section{1) Assay of malonyldialdehyde (MDA), the secondary product of lipid peroxi- dation}

Native semen $(2.7 \mathrm{ml})$ was incubated in the vessel of the Warburg apparatus at a temperature of $310 \mathrm{~K}$ and continuous shaking $(80 / \mathrm{min}$.) which ensured the aerobic conditions. Activator $(0.3 \mathrm{ml})$ was added through the side arm of the vessel after a 10 -minute long preincubation. In the control experiment, $0.3 \mathrm{ml}$ of $0.145 \mathrm{M} \mathrm{NaCl}$ was added instead of the activator.

Within given time intervals (60 or 90 minutes) the reaction was finished after the aerobic incubation both with and without the activator by addition of $3 \mathrm{ml} 20 \%$ trichloracetic acid. The aliquot of non-protein filtrate was mixed with equal volume of $0.5 \% 2$-thiobarbituric acid in $10 \%$. trichloracetic acid. After a 10-minute long heating to $373 \mathrm{~K}$ in boiling water bath, the sample was: quickly cooled to room temperature. The colour intensity of the mixture dependent on the amount of malonyldialdehyde was measured on a spectrophotometer UV-VIS Model 635 by Varian Techtron. at $532 \mathrm{~nm}$.

Calibration: reproducibility of the method was tested by measuring the extinction molar coefficient of the MDA for $532 \mathrm{~nm}$. Hydrolysis of $10^{-4}$ ethanol solution of 1,1,3,3-tetraethoxypropane(Fluka AG) with $0.7 \mathrm{M}$ hydrochloric acid (Schmidt 1959). From the calibration graph the extinction molar coefficient for MDA $\left(15.4 \mathrm{~m}^{2} \mathrm{~mol}^{-1}\right)$ was determined and employed for quantitative evaluation of the results.

\section{2) Determination of conjugated dienes}

in aerobically incubated boar semen with or without an activator was made using the method by Placer (1968) originally developed for measurement of conjugated dienes isolated from liver. tissue. For reproducible results it was necessary to extract only $0.5 \mathrm{ml}$ of semen after the finished aerobic incubation with or without the activator. The final heptane layer was measured in spectrophotometer (Specord UV-VIS, Zeiss Jena) at 200-350 $\mathrm{nm}$. The results were expressed in mmol of conjugated dienes per $10^{9}$ spermatozoa. The extinction molar coefficient for calculation of concentration of the conjugated dienes was used according to Placer et al. (1970).

Purification and control of the solvents employed was made according to Pestemer (1951). 
3) Oxidation of the coenzyme $\mathrm{NADPH}+\mathrm{H}^{+}$

resulting in its disappearence is also a measure of changes in the quality of unsaturated fatty acids during the lipid peroxidation (Hochstein and Ernster 1963; May and McCay 1968). The oxidation of NADPH $+\mathrm{H}^{+}$was followed in the system containing $2.7 \mathrm{ml} 0.1 \mathrm{M}$ phosphate buffer at $\mathrm{pH} 7.20$ or $0.1 \mathrm{M} \mathrm{KCl}-\mathrm{Tris}-\mathrm{HCl}$ buffer at $\mathrm{pH} 7.40$ and $0.1 \mathrm{ml}$ of the native boar semen, $3 \mathrm{mM}$ of pyrophosphate, $3 \mathrm{mM}$ NADPH $+\mathrm{H}^{+}$(final concentration in $3.0 \mathrm{ml}$ of total volume). The mixture was incubated at a temperature of $310 \mathrm{~K}$. Decrease in the amount of NADPH $+\mathrm{H}^{+}$was followed at $336 \mathrm{~nm}$ with help of a registration equipment (VITATRON) and was expressed in $\mu \mathrm{mol}$ of decreased coenzyme amount per minute and $\mathrm{ml}$ of semen.

The intracellular lipids of spermatozoa with high content of unsaturated fatty acids are concentrated besides the head also in the mitochondrial sheath of the middle piece of the tail; we therefore isolated the tails according to Ahluwalia and Holman (1969). For disintegration we used a fine sterile ball-balotine (No. 12) on a high-rotation laboratory shaker. The efectiveness of disintegration was controlled in a microscope. Finally, the centrifuged tails were stirred in cooled $0.154 \mathrm{M} \mathrm{NaCl}$ solution to obtain tails from $1 \mathrm{~g}$ of spermatozoa in $1 \mathrm{ml}$ of the suspension. This suspension covered with ice was processed immediately.

The course of enzymatic lipid peroxidation was followed in the system composed of $0.1 \mathrm{ml}$ sperm tail suspension, $4 \mathrm{mM}$ ADP, $3 \mathrm{mM}$ NADPH $+\mathrm{H}^{+}$(final concentration in total volume of $2.0 \mathrm{ml}$ ) in a phosphate buffer at $\mathrm{pH} 7.50$. The second system contained $0.1 \mathrm{M}$ Tris- $\mathrm{HCl}$ buffer at $\mathrm{pH} 7.52$.

\section{4) Anti-peroxidative activity of the boar seminal plasma}

The boar sperm was centrifuged $(3000 \mathrm{~g} / 10 \mathrm{~min}$.), the seminal plasma separated. A portion of the plasma was diluted in the phosphate buffer $(\mathrm{pH}$ 5.9) $1: 10$ to $1: 100$. Another portion of the plasma was left undiluted. For an active system, $10 \%$ homogenate of mouse liver was used. Immediately before use it was shortly centrifuged at $400 \mathrm{~g}$ and stored in ice (Placer 1968). The diluted and intact seminal plasma (both $0.5 \mathrm{ml}$ ) were added to $0.2 \mathrm{ml}$ homogenate in $4.0 \mathrm{ml}$ of buffer. The total volume $(4.7 \mathrm{ml}$ ) was incubated for 90 minutes. The MDA concentration in deproteined filtrate was measured. The inhibition percentage was calculated according to Vesell- $v$ va et al. (1967).

Statistical evaluation of the results was made according to Roth et al. (1962).

\section{Results}

The aerobic incubation alone of the boar semen does not result in measurable amount of MDA. Added inorganic $\mathrm{Cu}^{++}$ions increase considerably the production of MDA which is highest after 90 minutes. The spectral characteristics of the product of semen peroxidation $(\mathrm{Cu}++$, 60 min.) with the MDA standard prepared by acid hydrolysis of 1,1,3,3-tetraethoxypropane are shown in Fig. 1. The typical absorption curve of the MDA standard shows a sharp absorbance maximum at $532 \mathrm{~nm}$ corresponding to the MDA from the catalyzed peroxidation of the unsaturated fatty acids from phospholipids of the boar spermatozoa.

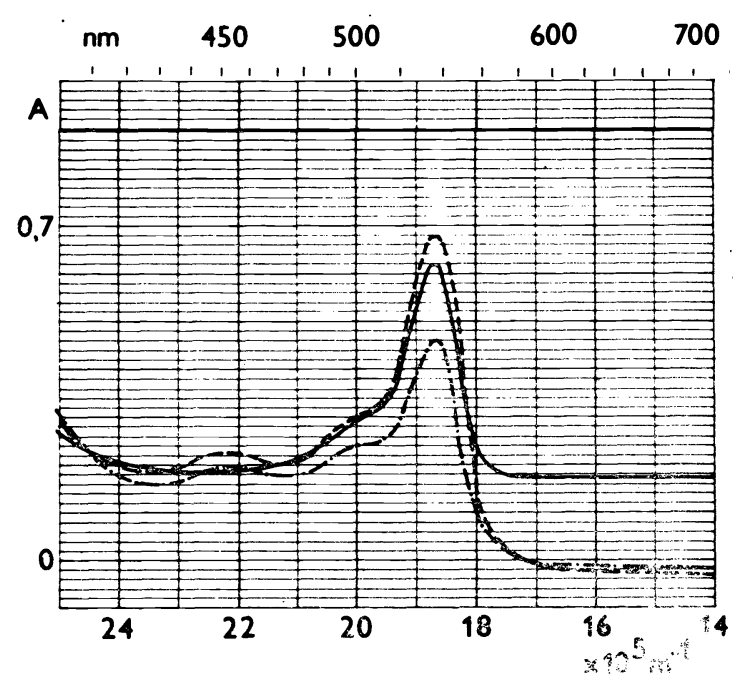

Fig. 1.

Comparative spectrum of the MDA standard and MDA from the catalyzed aerobic incubation of the boar semen

Legend of the Figure: MDA: standard -...-.-..-...-... semen No. 1 $\ldots \ldots$ semen No. 2 


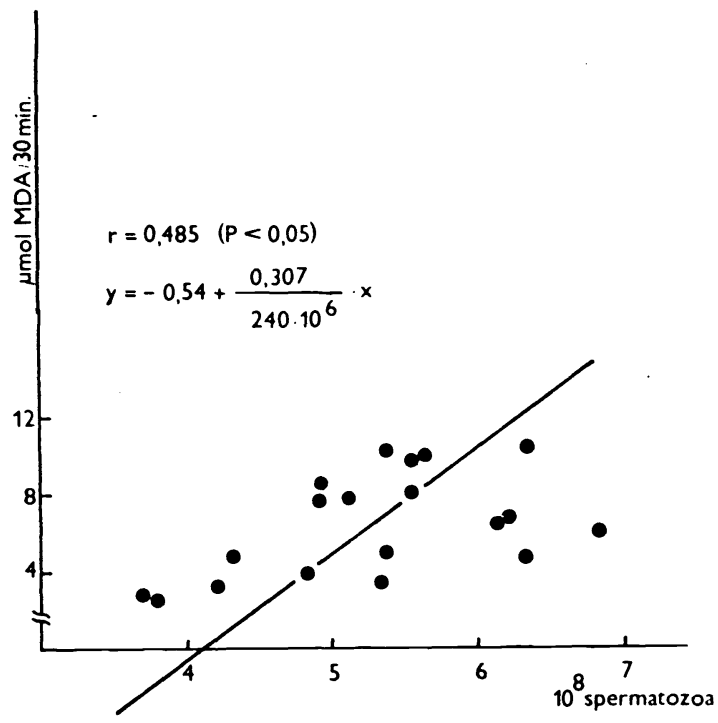

Fig. 2.

Relationship between the MDA production and concentration of spermatozoa in the boar semen at aerobic incubation with $\mathrm{Cu}^{++}$

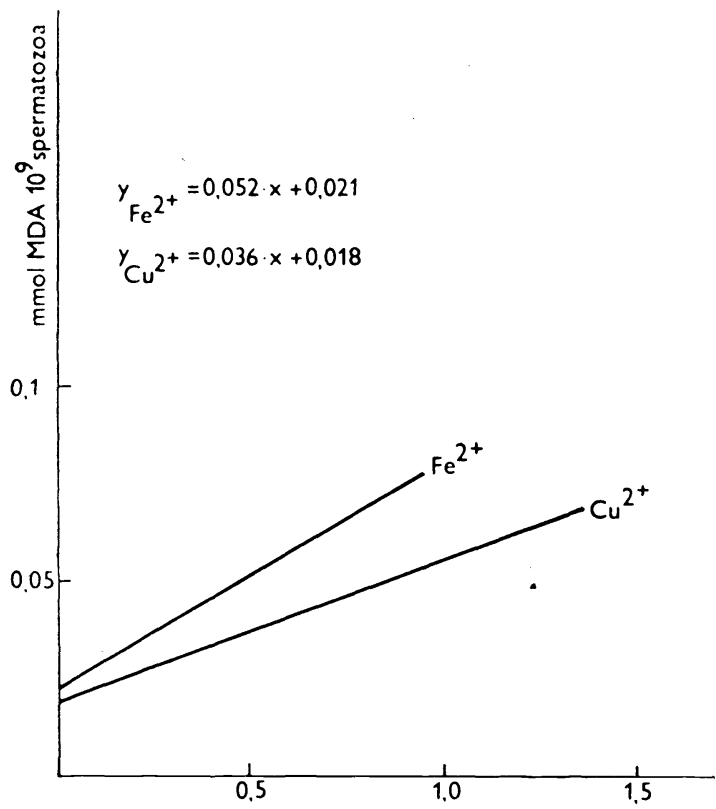

Fig. 3.

Relationship between the MDA and conjugated diene concentration in mmol $10^{9}$ spermatozoa
Peroxidation induced by the $\mathrm{Cu}^{++}$ions is dependent upon concentration of the activator and the reaction time. With decreasing activator concentration the reaction velocity slows down and the lowest $\mathrm{CuSO}_{4}$ concentration at which still measurable MDA production was found to be $2 \times 10^{-5} \mathrm{M}$ (Hruška et al. 1970). The optimum $\mathrm{CuSO}_{4}$ concentration inducing peroxidation of lipids in boar semen was $100 \times$ $\times 10^{-4} \mathrm{M}$ (final concentration in the incubated system $100 \times$ $\left.\times 10^{-5} \mathrm{M}\right)$. This concentration has been. used since in our laboratory.

The total yield of MDA produced in boar semen (20 specimens under identical experimental conditions) were examined depending on time during a catalyzed and non-catalyzed aerobic incubation is given in Table 1.

The amount of cellular elements (protein) present in the semen does not influence substantially the yield of MDA produced in the catalyzed aerobic incubation except for the first 30 minutes of incubation. The relationship between the final yield of MDA and the concentration of spermatozoa in boar semen expressed by a correlation coefficient $r=0.485$ was significant $(P<0.05)$; see Fig. 2. With increasing incubation time the correlation coefficient fell (at $60 \mathrm{~min} . r=0.346$ ) and at $90 \mathrm{~min}$. no correlation existed $(r=0.100)$.

The lipid peroxidation activity was also evaluated by a simultaneous determination of conjugated dienes in the lipid extract from the boar semen. Production of conjugated dienes was ob- 
Table 1

Influence of $\mathrm{Cu}^{++}$on production of MDA in the semen of the boar at aerobic incubation

\begin{tabular}{|c|c|c|c|}
\hline $\begin{array}{c}\text { Time- } \\
(\mathrm{min})\end{array}$ & $\begin{array}{c}\text { No. of examined semen } \\
\text { specimens }\end{array}$ & $\begin{array}{c}\text { Pure yield of MDA } \\
\left(\mu \mathrm{mol} \mathrm{MDA} / 10^{8} \text { sperms }\right)\end{array}$ & $\begin{array}{c}95 \% \text { confidence intervals } \\
\left(\mu \mathrm{mol} \mathrm{MDA} / 10^{8} \text { sperms }\right)\end{array}$ \\
\hline 30 & 20 & 1.213 & $1.015 \mathrm{azz} 1.411$ \\
60 & 20 & 2.275 & $1.874 \mathrm{azz} 2.676$ \\
90 & 20 & 3.498 & $2.926 \mathrm{azz} 4.070$ \\
\hline
\end{tabular}

served on induction of the lipid peroxidation by inorganic ions of $\mathrm{Fe}^{++}$and $\mathrm{Cu}^{++}$. The absorbance at $233 \mathrm{~nm}$ increased with the incubation time. Relationship between the concentration of MDA and conjugated dienes after $\mathrm{Fe}^{++}$and $\mathrm{Cu}^{++}$ activation is shown in Fig. 3. The $\mathrm{Fe}^{++}$ions are clearly more potent activator of the lipid peroxidation in the boar semen. In the early phase of lipid peroxidation with a low level of conjugated dienes (up to $1 \mathrm{mmol} / 10^{9}$ spermatozoa) a rapid MDA production occurs.

The oxidation of NADPH $+\mathrm{H}^{+}$is significantly influenced by the kind of the employed buffer. In the $\mathrm{KCl}$-Tris- $\mathrm{HCl}$ buffer at $\mathrm{pH} 7.40$ it was 3.5 times more rapid as compared to the reaction in phosphate buffer at the same $\mathrm{pH}$. The influence of pyrophosphate made itself felt in both cases by a mild slow-down of the NADPH $+\mathrm{H}^{+}$oxidation (Table 2).

The tails of spermatozoa carrying the mitochondrial sheath rich in lipids in their middle piece were subjected to the enzymatic NADPH-dependent lipid peroxidation. The results presented in Table 3 show that the $\mathrm{Cu}^{++}$ions enhance the peroxidation effect of NADPH 2.3 times and the $\mathrm{Fe}^{++}$ions 2.6 times. The stimulatory effect of ADP in concentration of $4 \mathrm{mM}$ was not so obvious (21\%) as was the case with mitochondrial and microsomal suspensions (Placer 1967; Hochstein and Ernster 1963). Also the type of the employed buffer made itself felt to a certain degree.

In connection with the study of lipid peroxidation in the boar semen it was

Table 2

Oxidation of NADPH $+\mathbf{H}^{+}$

\begin{tabular}{|c|c|}
\hline & $\begin{array}{c}\text { Decrease } \\
\text { in } \mathrm{NADPH}+\mathrm{H}^{+} \\
\text {amount } \\
(\mu \mathrm{mol} 1 / \mathrm{min} .1 / \mathrm{ml} \text { semen })\end{array}$ \\
\hline $\begin{array}{l}\text { Phosphate buffer pH } 7.2 \\
\text { NADPH }+\mathrm{H}^{+}\end{array}$ & 48.81 \\
\hline $\mathrm{NADPH}+\mathrm{H}^{+}+\mathbf{P P}$ & 39.51 \\
\hline $\begin{array}{l}\mathrm{KCl}-\text { Tris }-\mathrm{HCl} \\
\text { buffer } \mathrm{pH} 7.4 \\
\mathrm{NADPH}+\mathrm{H}^{+}\end{array}$ & 172.98 \\
\hline $\mathrm{NADPH}+\mathrm{H}^{+}+\mathbf{P P}$ & 158.16 \\
\hline
\end{tabular}

Total volume: $3.0 \mathrm{ml}$
Table 3

Enzymatic lipid peroxidation

\begin{tabular}{|c|c|}
\hline Activator & $\begin{array}{c}\text { Decrease } \\
\text { in } \mathrm{NADPH}+\mathrm{H}^{+} \\
\begin{array}{c}\mu \mathrm{mol} / 1 \mathrm{~min} . \\
\text { suspension }\end{array}\end{array}$ \\
\hline $\begin{array}{l}\text { NADPH }+\mathrm{H}^{+} \\
(\text {Tris }-\mathrm{HCl} \text { buffer } \\
\text { pH 7.52) }\end{array}$ & 9.44 \\
\hline $\mathrm{NADPH}+\mathrm{H}^{+}+\mathrm{Cu}^{2+}$ & 21.90 \\
\hline $\mathrm{NADPH}+\mathrm{H}^{+}+\mathrm{Fe}^{2+}$ & 24.70 \\
\hline $\begin{array}{l}\text { NADPH }+\mathrm{H}^{+} \\
\text {(phosphate buffer pH7.5) }\end{array}$ & 11.61 \\
\hline $\mathrm{NADPH}+\mathrm{H}^{+}+\mathrm{ADP}$ & 14.16 \\
\hline $\begin{array}{l}\mathrm{NADPH}+\mathrm{H}^{+}+ \\
+\mathrm{ADP}+\mathrm{Cu}^{2+}\end{array}$ & 19.05 \\
\hline
\end{tabular}

Total volume: $2.0 \mathrm{ml}$ 
of interest to explore if and to what extent the seminal plasma is capable to inhibit the lipid peroxidation activity of some other biological system. Table 4 shows that the seminal plasma diluted $1: 10$ to $1: 30$ has a high anti-peroxidative activity which tends to decrease with its increasing dilution. No anti-peroxidative activity of undiluted seminal plasma of the boar is given in the Table as we failed to eliminate turbidity of the parallel samples after deproteination. In the repeated experiments, however, this problem was solved and we detected a $92 \%$ anti-peroxidative activity of the undiluted seminal plasma. This inhibitory activity is connected with the macromolecular substances of the seminal plasma and it does not disappear during dialysis.

Table 4

Inhibitory activity of the seminal plasma of the boar

\begin{tabular}{|c|c|c|c|}
\hline & & $\begin{array}{c}\text { Activity of the lipid- } \\
\text { peroxidative system } \\
(\mu \text { mol MDA })\end{array}$ & $\begin{array}{c}\text { Inhibition of lipid } \\
\text { peroxidation } \\
(\%)\end{array}$ \\
\hline 1. & Without seminal plasma & 210 & 0 \\
2. & With seminal plasma $1: 10$ & 100 & 52.3 \\
& $1: 20$ & 120 & 43 \\
$1: 30$ & $1: 40$ & 150 & 40.4 \\
& $1: 50$ & 155 & 26 \\
& $1: 100$ & 185 & 12 \\
\hline
\end{tabular}

Total volume $4.7 \mathrm{ml}$, incubation $90 \mathrm{~min}$.

\section{Discussion}

The vast knowledge on lipid peroxidation and changes of the polyunsaturated fatty acids of phospholipids contained in mitochondrial membranes, in microsomes, lysosomes, chloroplasts and in other natural and artificial systems indicate a connection of these changes with impairment of membranes. They provide a broad basis for the study of these questions in spermatozoa. Recent results show that lipid peroxidation of the fatty acids of sperm lipids of the boar in vitro can proceed under certain conditions, and that it mirrors some influences upon the spermatozoa. Thorough analysis of these facts can lead to practical conclusions necessary for field insemination.

Demonstration of the lipid peroxidative activity in the native boar sperm can be regarded as a contribution to the general physiology and cell metabolism because up to now the in vivo lipid peroxidation had been connected with the toxic effect of oxygen on cellular level (Haugaard 1968), with the cellular mechanisms of senescence (Barber and Bernheim 1967; Chio et al. 1969; Oku$\mathrm{ma}$ et al. 1969), with damage to liver parenchyma in $\mathrm{CCl}_{4}$ intoxication (Recknagel 1967) and especially with insufficient antioxidant ability of tissues connected with lack of vitamin $\mathrm{E}$ and selenium (Kitabchi et al. 1960, 1968; Zalkin and Tappel 1960).

At the aerobic incubation of boar sperm with $\mathrm{Cu}^{++}$ions a significant dependence between the concentration of spermatozoa in the semen and MDA occurrence during the first 30 minutes of incubation was demonstrated. The correlation coefficient $r=0.485(P<0.05)$ indicates that the number of spermatozoa is not the only and decisive factor of lipid peroxidation. The changing amount of seminal plasma can make itself felt by varying lipid antiperoxidation activity. 
MDA is produced progressively in the early stage of peroxidation. Therefore we consider its determination in these stages to be a more valuable and reproducible indicator of peroxidative activity than determination of conjugated dienes which in turn is being used for evaluation of long-time catalyzed aerobic incubation (Placer et al. 1970; Goldstein and Harber 1972; Tsai 1975).

$\mathrm{The} \mathrm{Fe}^{++}$ions are highly aggressive in the peroxidative reaction which is in agreement with their oxidoreduction properties. In the reduced state they are probably maintained in the reaction by the ascorbic acid which is a natural component of boar semen.

Connection of NADPH $+\mathrm{H}^{+}$with pyrophosphate had no stimulatory effect as described with mitochondrial and microsomal suspensions from rat liver (Placer 1967; Tam and McCay 1970). One-minute long exposure to a temperature of $343 \mathrm{~K}$ inactivated the system, the oxidation of coenzyme did not proceed but the final reaction with thiobarbituric acid was weakly positive. This finding is different from that of the course of peroxidation of microsomal fraction from rat liver which is also NADPH-dependent but highly labile to the effect of temperature (May and McCay 1968).

From the viewpoint of profound study of lipid peroxidation we consider important to follow the interaction of organic peroxides with-SH groups of proteins and enzymes in the semen.

We-express thanks for the experimental material to doc. MVDr. Podaný CSc. and MVDr Věžník CSc. Veterinary Research Institute in Brno and for the technical cooperation to Mrs. Cechová

\section{Lipoperoxidace ve spermatu kance}

Při katalyzované aerobní inkubaci celého ejakulátu kance dochází $\mathrm{k}$ tvorbě malonyldialdehydu, který je všeobecně uznávaným indikátorem peroxidačního odbourávání polynenasycených mastných kyselin. Detekce produktů peroxidace byla prováděna jednak barevnou reakcí s kyselinou 2-thiobarbiturovou (průkaz malonyldialdehydu) a jednak spektrofotometricky (průkaz konjugovaných dienů, oxidace koenzymu NADPH $+\mathrm{H}^{+}$). Zjistili jsme, že progresivní tvorba malonyldialdehydu převažuje zejména $\mathrm{v}$ časných stadiích peroxidace nad vznikem konjugovaných dienů. Mezi počtem spermií v ejakulátu (substrát pro reakci) a množstvím vzniklého malonyldialdehydu byla shledána významná korelace pro počátečních 30 minut aerobní inkubace.

Enzymatická lipoperoxidace, studovaná na izolovaných bičících spermií kance je NADPH-dependentní s malou závislostí na pyrofosfátu. Tvorba malonyldialdehydu ve všech studovaných systémech byla citlivě ovlivňována $\mathrm{pH}$ prostředí.

Semenná plasma kance se vyznačovala vysokou antiperoxidační aktivitou limitovanou ředěním.

Образование перекиси липидов в сперме борова

При катализированной аэробной инкубации эякулята борова в целом имеет место образование малонового диальдегида, являющегося общепризнанным индикатором перекисного расщепления полиненасыщенных жирных кислот. Обнаружение продуктов получения перекиси проводилось цветной реакцией с 2-тиобарбитуровой кислотой (определение малонового диальде- 
гида), а также спектрофотометрически (определение сопряженных диеновых соединений, окисление кофермента НАДПГ $+\mathrm{H}^{+}$). Было установлено, что прогрессивное образование малонового диальдегида преобладает в особенности на ранней стадии получения перекиси по сравнению с образованием сопряженных диенов. Между количеством спермий в эякуляте (субстрат для реакции) и количеством возникшего малонового диальдегида была установлена значимая коррелящия для первоначальных 30 минут аэробной инкубации.

Энзиматическое образование перекиси липидов, изучаемое на изолированных семенных нитях спермий борова, НАДПГ-забисим с небольшой зависимостью от пирофосфата. Образование малонового диальдегида в всех изучаемых системах находилось под чувствительным влиянием $\mathrm{pH}$ среды.

Семенная плазма борова отличалась высокой противоперекисной активностью, определяемой разбавлением.

\section{References}

AHLUWALIA, B. - HOLMAN, R. T.: Fatty acid composition of lipids of bull, boar, rabbit and human semen. J. Reprod. Fert., 18, 1969: 431-437.

BARBER, A. A. - BERNHEIM, F.: Lipid peroxidation; its measurements, occurrence and significance in animal tissues. Adv. Gerontol. Res., 2, 1967: 355-403.

GERBER, G. I. - ALTMAN, K. I.: Radiation Biochemistry. New York, Academic Press, Vol. II, 1970: 30. In: SUZUKI, S. - AKAMATSU, Y.: Involvement of membrane lipids in radiation damage to potassium -ion permeability of Escherichia coli. Int. J. Radiat. Biol., 33, 1978: $185-190$.

GOLDSTEIN, B. D. - HARBER, L. C.: Erythropoietic protoporphyria: Lipid peroxidation and red cell membrane damage associated with photohemolysis. J. clin. Invest., 51, 1972: 892-902.

HAUGAARD, N.: Physiol. Rev. 48, 1968: 311. In: CHIO, K. S. - REISS, U. - FLETCHER, B. - TAPPEL, A. L.: Peroxidation of subcellular organelles: Formation of lipofuscin-like pigments. Science, 166, 1969: 1535-1536.

HEIKKILA, R. E. - MEZICK, J. A. - CORNWELL, D. G.: Destruction of specific membrane phospholipids during peroxidative hemolysis of vitamin E deficient erythrocytes. Physiol. Chem. Physics, 3, 1971: 93-97.

HICKS, M. - GEBICKI, J. M.: Peroxidative damage in linoleic acid membranes. Proc. Aust. Biochem. Soc., 10, 1977: 90.

HOCHSTEIN, F. - ERNSTER, L.: ADP-activated lipid peroxidation coupled to the TPNH oxidase system of microsomes. Biochem. biophys. Res. Commun., 12, 1963: 388-394.

HRUSKKA, K. - SMUTNÁ, M. - KOZUMPLÍK, J.: Peroxidace lipidů kančích spermií Reprodukce a genetika hospodářských zviřat, II. 1970: 30-35.

CHIO, K. S. - REISS, U. - FLETCHER, B. - TAPPEL, A. L.: Peroxidation of subcellular organelles: Formation of lipofuscin-like pigments., Science 166, 1969: 1535-1536.

JOHNSON, L. A. - GERRITS, R. J. - YOUNG, E. P.: Quantitative analysis of porcine spermatozoa and seminal plasma phospholipids as affected by frequency of ejaculation. J. Reprod.' Fert., 19, 1969a: 95-102.

JOHNSON, L. A. - GERRITS, R. J. - YOUNG, E. P.: The fatty acid composition of porcine spermatozoa phospholipids. Biol. Reprod., 1, 1969b: 330-334.

JOHNSON, L. A. - PURSEL, V. G. - GERRITS, R. J.: Total phospholipids and phospholipid fatty acids of ejaculated and epididymal semen and seminal vesicle fluids of boars. J. Anim. Sci., 35, 1972: 398-403.

JONES, R. - MANN, T.: Lipid peroxidation in spermatozoa. Proc. Roy. Soc., B 184, 1973: 103-107.

JONES, R. - MANN, T.: Lipid peroxides in spermatozoa; formation, role of plasmalogen and physiological significance. Proc. Roy, Soc., B 193, 1976: 317-333.

JONES, R. - MANN, T.: Damage to ram spermatozoa by peroxidation of endogenous phospholipids. J. Reprod. Fert., 50, 1977: 261-268.

KITABCHI, E. A. - MCCAY, PB. - CARPENTER, M. P. - TRUCCO, R. E. - CAPUTTO, R.: Formation of malonaldehyde in vitamin $\mathrm{E}$ deficiency and its relation to the inhibition of gulonolactone oxidase. J. biol. Chem., 235, 1960: 1591-1599. 
KITABCHI, E. A. - CHALLONER, D. R. - WILLIAMS, R. H.: Respiration and lipid peroxidation in tocopherol deficient rat hearts. Proc. Soc. exp. Biol. Med., 127, 1968: 647-650.

MAY, H. E. - McCAY, P. B.: Reduced triphosphopyridine nucleotide oxidase-catalyzed al terations of membrane phospholipids. I. Nature of the lipid alterations. J. biol. Chem., 243, 1968: $2288-2295$.

McLEOD, L.: The role of oxygen in the metabolism and motility of human spermatozoa. Am. J. Physiol., 138, 1943: 512-518.

MROTEK, J. J. - HOEKSTRA, W. G. - FIRST, N. L.: Effect of boar semen senility on peroxidation of semen lipids., J. Anim. Sci. 25, 1966: 688-692.

OKUMA, M. - STEINER, M. - BALDINI, M.: Lipid peroxidation in aging platelets., Blood 34, 1969: 712-716.

PESTEMER, M.: Lösungsmitteln Reinigung für spektroskopische Zwecke. Angew. Chem., 63, 1951: $118-122$.

PLACER Z.: Lipoperoxydationssystems von Subzellularpartikeln. Nahrung, 11, 1967: 623-627.

PLACER, Z.: Lipoperoxydationssysteme im biologischen Material. 2. Mitt. Bestimmung der Lipoperoxydation im Säugetierorganismus. Nahrung, 12, 1968: 679-684.

PLACER, Z. - VIDLÁKOVÁ, M. - KUŽELA, L.: Lipid peroxidation processes in liver damage and steatosis. Rev. Czech. Med., 16, 1970: 29-39.

PRINCE, M. J. - ALMQUIST, J. O.: The effect of agitation upon the livability of bovine spermatozoa. J. Dairy Sci. 31, 1948: 839-843.

RECKNAGEL, R. O.: Carbon tetrachloride hepatotoxicity. Pharmacol. Rev., 19, 1967: 145-208.

ROTH, Z. - JOSÍFKO, M. - MALÝ, V. - TRČKA, V.: Statistické metody v experimentální medicinè. Praha 1962.

SCHMIDT, H.: Die Thiobarbitursäurezahl als Maß für den Oxydationsgrad von Nahrungsfetten. Fette Seifen AnstrMittel, 61, 1959: 127-138.

SMUTNÁ, M.: Výzkum peroxidace mastných kyselin a metabolismus fosfolipidů spermíi. Project report VƯ P 11-329-051-05/03, VŠV Brno, 1974: 63 pp.

SUZUKI, S. - AKAMATSU, Y.: Involvement of membrane lipids in radiation damage to potassium-ion permeability of Escherichia coli. Int. J. Radiat. Biol., 33, 1978: 185-190.

TAM, B. - McCAY, P. B.: Reduced triphosphopyridine nucleotide oxidase-catalyzed alterations of membrane phospholipids. III. Transient formation of phospholipid peroxide. J. biol. Chem., 245, 1970: 2295-2300.

TSAI, A. C.: Lipid peroxidation and glutathione peroxidase activity in the liver of cholesterol-fed rats. J. Nutr., 103, 1975: 946-951.

VESELKOVÁ, A. - VIDLÁKOVÁ, M. - PLACER, Z.: Estimation of the effectiveness of antioxidants by means of synthetic lipoperoxidation systems. J. Hyg. Epidem. Microbiol. Immun., 11, 1967: 246-253.

ZALKIN, H. - TAPPEL, A. L.: Studies on the mechanism of vitamin E action. IV. Lipid peroxidation in the vitamin E deficient rabbit. Archs. Biochem. Biophys., 88, 1960: 113-117. 